\title{
STUDY OF RED CELL INDICES AND RETICULOCYTE COUNT IN PERSON WITH ANEMIA AT A TERTIARY CARE HOSPITAL OF KATHMANDU
}

\author{
Pudasaini $\mathcal{S}^{1}$, Pant $P P^{2}$, Kafle $N^{1}$, Maharjan $\boldsymbol{S}^{1}, K C A^{1}$, Shrestha $\boldsymbol{S}^{1}$
}

${ }^{1}$ Department of Pathology, ${ }^{2}$ Department of Community Medicine, Nepal Medical College Teaching Hospital, Gokarneshwor-8, Kathmandu, Nepal

\begin{abstract}
Anemia is not a disease but a clinical feature of some other underlying problems. It is one of the most common public health problems in developing countries. The prevalence of anemia differs according to the age group. A cross sectional observational study was conducted in a tertiary hospital, over a period of six months (January 2018 to June 2018). All the cases of anemia in different age group with hematological investigations (hemoglobin and red blood cell indices) including reticulocyte count during the study period were included. A total of 274 blood samples of persons with anemia were evaluated. The mean age of the patients was $41.4 \pm 25.37$ years. Anemia was more commonly seen in females $(68.2 \%)$ than males $(31.8 \%)$ in our study. The most affected age group for anemia was person $\geq 15$ years followed by children $<5$ years. The least affected group was children of 12-14 years. Microcytic anemia (decreased MCV and decreased MCHC) was observed in children of 12-14 years and macrocytic anemia (increased MCV) was seen in group $\geq 15$ years. Red cell distribution width (RDW) was more elevated in children of $12-14$ years and showed that there was significant variation of size of RBC in this group. Reticulocyte count was higher in children $<5$ years and lower in children of 12- 14 years. Significant correlation was noted for hematocrit and reticulocyte count. This study revealed that the prevalence of anemia increases with age and was more common in females. Baseline study of red blood cell indices and reticulocyte count will help us in diagnosing the type of anemia and in further management.
\end{abstract}

\section{KEYWORDS}

Anemia, hemoglobin, hematocrit, red cell indices, reticulocyte

\section{CORRESPONDING AUTHOR}

Dr. Sujata Pudasaini, Associate Professor,

Department of Pathology,

Nepal Medical College Teaching Hospital,

Attarkhel, Gokarneshwor-8, Kathmandu, Nepal,

Email: sujatapudasaini@gmail.com 


\section{INTRODUCTION}

Anemia is a global health problem..$^{1}$ It is not a disease but it is the expression of underlying diseases. It is important to know the cause of anemia to treat the patients. ${ }^{2}$ Anemia is defined as the decrease in Red blood cell (RBC), hemoglobin ( $\mathrm{Hb}$ ) and hematocrit (Hct) level below the lower extreme of the normal range for the age and sex of the individual. ${ }^{1-3}$ According to WHO, the anemia cut offs are different for different age group. The hemoglobin cut offs for anemia is- for children 6- 59 months of age- $11 \mathrm{gm} \%$, children 5-11 years of age- $11.5 \mathrm{gm} \%$, children 12 14 years of age- $12 \mathrm{gm} \%$, non pregnant women (15 years and above)- 12 gm\%, pregnant women - 11 gm $\%$ and men (15 years and above) - 13 gm $\%{ }^{4}$

The prevalence of anemia is usually high in females when compared to males. ${ }^{5}$ Another group of person affected with anemia are children of 5- 14 years. ${ }^{6}$ To find out the type of anemia, the laboratory test should include $\mathrm{Hb}$, Hct and $\mathrm{RBC}$ indices which include mean corpuscular volume (MCV), mean corpuscular hemoglobin $(\mathrm{MCH})$, mean corpuscular hemoglobin concentration (MCHC) and red cell distribution width (RDW). ${ }^{3} \mathrm{MCV}$ is the average volume of red cell expressed in femtoliters (fl). MCH is the average content of $\mathrm{Hb}$ per red cell, expressed in picograms (pg). $\mathrm{MCHC}$ is the average concentration of $\mathrm{Hb}$ in a given volume of packed red cells, expressed in grams per deciliter (gm/dl). RDW is the coefficient of variation of red cell volume expressed as RDW-CV (\%) and RDW- SD (fl). ${ }^{3}$ The study of RBC parameters is an effective way of quantitative assessment of $\mathrm{RBC}$. RBC indices provide important guidelines for the diagnosis, classification and monitoring the treatment of anemia.?

Morphological classification of anemia shows three types of anemia. The most common type is microcytic hypochromic anemia which shows reduced MCV (mean corpuscular volume) $<80 \mathrm{fl}$ and reduced MCHC (mean corpuscular hemoglobin concentration) $<30 \mathrm{gm} / \mathrm{dl}$. Normocytic normochromic anemia has normal MCV (82- $100 \mathrm{fl}$ ) and macrocytic anemia has MCV $>100 \mathrm{fl}$ and normal MCHC. ${ }^{2,3}$ Reticulocytes are the non nucleated immature erythroid cells in the peripheral blood that are in a discrete penultimate phase of maturation. ${ }^{8,9}$ The reticulocytes percentage in the peripheral blood is an indication of the rapidity of red cell turnover if the patient is in a steady state. ${ }^{8,10} \mathrm{~A}$ low reticulocyte percentage reflects a marrow unable to compensate for anemia and a high reticulocyte percentage reflects a marrow that is attempting to compensate for red cell destruction or recovering from anemia. ${ }^{8}$

The red cells parameters $(\mathrm{MCV}, \mathrm{MCH}, \mathrm{MCHC}$ and RDW) given by automated haematology cell counter are very relevant for the diagnosis of anemia. Reticulocyte count also plays a major role in giving the clue for diagnosis and also in monitoring the bone marrow recovery. Hence, it is worthwhile to evaluate these parameters in person with anemia.

\section{MATERIALS AND METHODS}

This was a cross sectional observational study done in a department of Pathology of a tertiary hospital (Nepal Medical College Teaching Hospital, NMCTH) for a period of six months (January 2018 to June 2018). Ethical approval was taken from Institutional Review Committee (IRC) of NMCTH. A total number of 274 cases of anemia (on the basis of definition as per WHO criteria) along with reticulocyte count during the study period were included. Relevant clinical history of the patients was obtained from the patient's file. Children under 6 months, pregnant females and patients with chronic illness (heart diseases and kidney diseases) were excluded from the study.

Ethylene diamine tetra acetic acid (EDTA) anticoagulated blood sample of in patient and OPD patient was run in Sysmex 5 parts hematology automatic cell counter- XS- 500i. Investigations like $\mathrm{Hb}, \mathrm{Hct}, \mathrm{RBC}$ indices (MCV, MCH, MCHC and RDWCV) were obtained. The slides for reticulocyte count were prepared by mixing the blood sample with equal amount of dye (New methylene blue).The mixture was then incubated at $37^{\circ} \mathrm{C}$ for 15 minutes and the film was prepared on the slide. After drying the slide, reticulocytes were counted under the oil immersion.

The value of Hb, Hct, RBC indices and reticulocyte count was obtained and entered in MS Excel 2003. Analysis was done using SPSS (Statistical Package for Social Sciences) version 16.

Age wise distribution of $\mathrm{Hb}$, Hct, MCV, MCH, MCHC, RDW and reticulocyte count was found out. Mean of each variables were compared with different age group. ANOVA test was applied. The level of significance $(\infty)$ was set at $5 \%$ and $p$ value $<0.05$ was considered significant.

\section{RESULTS}

There were 975 samples of Complete blood count (CBC) and out of this 274 cases had anemia during the study period. The prevalence of anemia in our hospital during the study period was $28.1 \%$. The age of the person with anemia ranged from 6 months to 93 years with the mean age of $41.40 \pm 25.37$. Anemia was more commonly seen in female $(68.2 \%)$ than male (31.8\%). (Fig. 1)

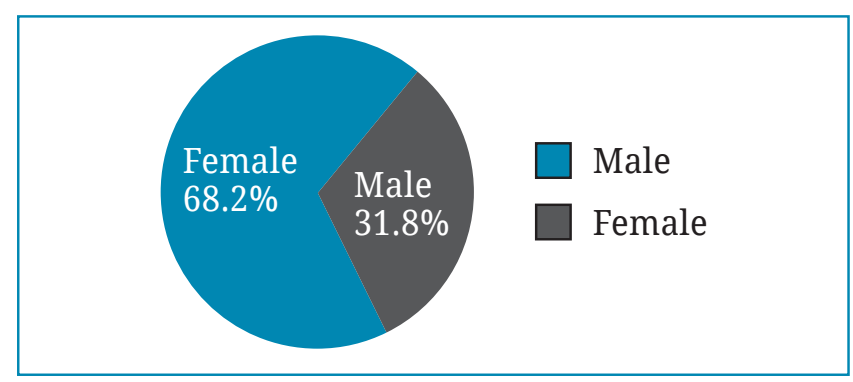

Fig. 1: Sex wise distribution of anemia 
Anemia was most commonly seen in the age group $\geq 15$ years $(82.2 \%)$ followed by age group, children < 5 years $(14.6 \%)$. (Figure 2$)$

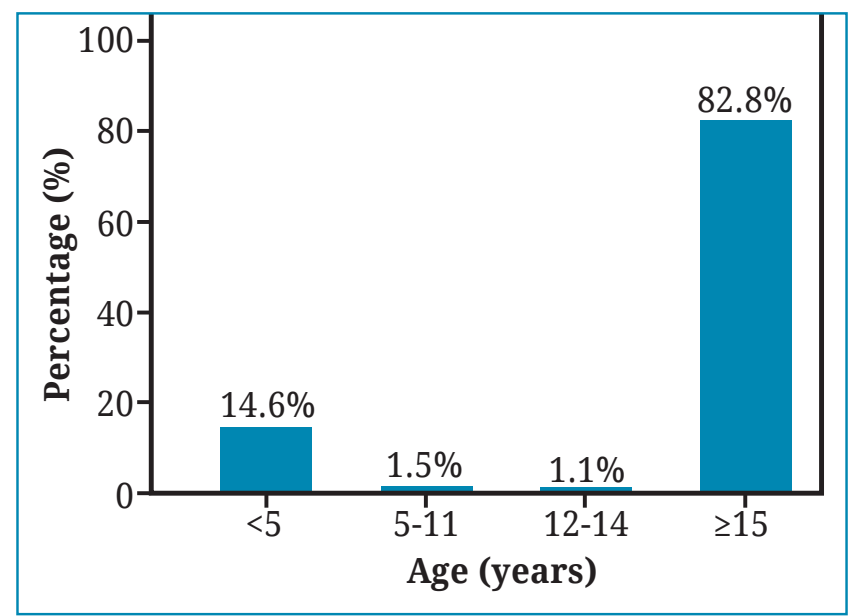

Fig. 2: Age wise distribution

Females of age group $\geq 15$ years were found to be affected more with anemia (59.5\%) followed by male $(31.8 \%)$ in the same age group (Table-1).

\begin{tabular}{|lccc|}
\multicolumn{4}{|l}{ Table-1: Age and sex wise distribution of anemia } \\
\hline $\begin{array}{l}\text { Age } \\
\text { (years) }\end{array}$ & Female & Male & Total \\
$<5$ & $\mathrm{n}(\%)$ & $\mathrm{n} \mathrm{( \% )}$ & $\mathrm{n} \mathrm{( \% )}$ \\
$5-11$ & $19(16.9)$ & $21(7.7 \%)$ & $40(14.6 \%)$ \\
$12-14$ & $2(0.7 \%)$ & $2(0.7 \%)$ & $4(1.5 \%)$ \\
$\geq 15$ & $3(1.1 \%)$ & $0(0 \%)$ & $3(1.1 \%)$ \\
Total & $163(59.5 \%)$ & $64(23.4 \%)$ & $227(82.8 \%)$ \\
\hline
\end{tabular}

The mean Hct value was $29.39 \pm 7.80$. The mean Hct was significantly different among the age groups. Mean Hct level was lowest in children of 12-14 years and high in children $<5$ years (Table-2).

\section{Table-2: Agewise comparison of Hct levels}

\begin{tabular}{|llcc}
$\begin{array}{l}\text { Age } \\
\text { (years) }\end{array}$ & Mean \pm SD & $\begin{array}{c}\text { Sample } \\
\text { Mean } \pm \text { SD }\end{array}$ & P value \\
$<5$ & $32.93 \pm 7.47$ & & \\
$5-11$ & $30.72 \pm 6.24$ & & \\
$12-14$ & $27.30 \pm 4.15$ & $29.39 \pm 7.80$ & 0.018 \\
$\geq 15$ & $28.78 \pm 7.77$ & & \\
\hline
\end{tabular}

Comparison of mean MCV values in different age group was shown in Table-3. Low MCV (65.33 \pm 5.46) was seen in children of age group 12- 14 years and high MCV was seen in age group, $\geq 15$ years. This showed that microcytic hypochromic anemia was common in growing children and macrocytic anemia was common in adult patients. Similarly, $\mathrm{MCH}$ was also very much decreased in children of 12- 14 years (Table-4). Decreased MCH is suggestive of hypochromic anemia.
Table-3: Agewise comparison of MCV values

\begin{tabular}{|lccc|}
$\begin{array}{l}\text { Age } \\
\text { (years) }\end{array}$ & Mean \pm SD & $\begin{array}{c}\text { Sample } \\
\text { Mean } \pm \text { SD }\end{array}$ & $\begin{array}{c}\text { P } \\
\text { value }\end{array}$ \\
$<5$ & $80.34 \pm 12.73$ & & \\
$5-11$ & $80.70 \pm 5.65$ & $108.60 \pm 4.74$ & 0.975 \\
$12-14$ & $65.33 \pm 5.46$ & & \\
$\geq 15$ & $114.64 \pm 5.21$ & & \\
\hline
\end{tabular}

Table-4: Agewise distribution of MCH values

\begin{tabular}{llcc|} 
Age & Mean \pm SD & $\begin{array}{c}\text { Sample } \\
\text { Mean } \pm \text { SD }\end{array}$ & $\begin{array}{c}\text { P } \\
\text { value }\end{array}$ \\
$<5$ & $25.57 \pm 5.19$ & & \\
$5-11$ & $25.77 \pm 3.67$ & & \\
$12-14$ & $18.90 \pm 2.00$ & $24.79 \pm 5.26$ & 0.185 \\
$\geq 15$ & $24.71 \pm 5.28$ & & \\
\hline
\end{tabular}

MCHC decreases when MCV is decreased as it is a measure of the average concentration of $\mathrm{Hb}$ inside a single RBC. MCHC was decreased in all age group except in group $\geq 15$ years. The lowest value of MCHC was seen in children of 12-14 years who showed low MCV (Table-5).

Table-5: Agewise distribution of MCHC values

\begin{tabular}{|lccc|} 
Age & Mean \pm SD & $\begin{array}{c}\text { Sample } \\
\text { Mean } \pm \text { SD }\end{array}$ & P value \\
$<5$ & $31.34 \pm 1.76$ & & \\
$5-11$ & $30.40 \pm 2.36$ & $32.64 \pm 24.94$ & 0.971 \\
$12-14$ & $28.96 \pm 2.31$ & & \\
$\geq 15$ & $32.96 \pm 27.39$ & & \\
\hline
\end{tabular}

RDW was increased in all age group. (Table-6) Increased RDW values indicate greater variation in size of the RBCs. The variation was more in case of children of 12- 14 years which showed the presence of microcytic hypochromic anemia in this age group.

\section{Table-6: Agewise distribution of RDW values}

\begin{tabular}{llcl} 
Age & Mean \pm SD & $\begin{array}{c}\text { Sample } \\
\text { Mean } \pm \text { SD }\end{array}$ & P value \\
$<5$ & $16.18 \pm 2.61$ & & \\
$5-11$ & $15.07 \pm 1.37$ & & \\
$12-14$ & $17.03 \pm 1.95$ & $16.47 \pm 3.31$ & 0.755 \\
$\geq 15$ & $16.54 \pm 3.45$ & & \\
\hline
\end{tabular}

Reticulocyte count was slightly reduced in children of $12-14$ years. However in other age group it was within the normal range (Table-7).

\begin{tabular}{lccc}
\multicolumn{4}{c}{ Table-7: Agewise distribution of Reticulocyte } \\
Age & Mean \pm SD & Sample & P value \\
$<5$ & $2.59 \pm 2.16$ & & \\
$5-11$ & $0.60 \pm 0.40$ & $1.41 \pm 1.45$ & 0.000 \\
$12-14$ & $0.40 \pm 0.30$ & & \\
$\geq 15$ & $1.23 \pm 1.20$ & & \\
\hline
\end{tabular}


When different variables are compared with male and female, Hct and MCH was significant. (Table-8)

\begin{tabular}{|clcccc}
\multicolumn{6}{|c}{ Table-8: Sexwise comparison with Hct, MCV, MCH, } \\
\hline \multirow{5}{*}{ MCHC, RDW and Reticulocyte } \\
& Sex & (n) & Mean & $\begin{array}{c}\text { Std. } \\
\text { Deviation }\end{array}$ & P value \\
Hb & Male & 87 & 8.700 & 2.6005 & 0.134 \\
& Female & 187 & 10.187 & 9.0383 & \\
Hct & Male & 87 & 27.651 & 7.7366 & 0.011 \\
& Female & 187 & 30.212 & 7.7158 & \\
MCV & Male & 87 & 83.295 & 13.4339 & 0.548 \\
& Female & 187 & 120.374 & 574.8973 & \\
MCH & Male & 87 & 25.879 & 5.6968 & 0.020 \\
& Female & 187 & 24.290 & 4.9817 & \\
MCHC & Male & 87 & 34.299 & 32.7216 & 0.455 \\
& Female & 187 & 31.874 & 20.4070 & \\
RDW & Male & 87 & 17.003 & 3.8797 & 0.072 \\
& Female & 187 & 16.229 & 2.9937 & \\
Retics & Male & 87 & 1.585 & 1.6605 & 0.196 \\
& Female & 187 & 1.340 & 1.3541 & \\
\hline
\end{tabular}

\section{DISCUSSION}

Anemia affects both developing and developed countries and is more common in children and females of reproductive age group. It is such an important issue affecting a large population worldwide. ${ }^{2}$ Blood cell index gives us quantitative assessment of RBCs. Advent of automated hematology cell counter has not only improved accuracy and precision but has also reduced subjective errors. ${ }^{1}$

The prevalence of anemia is an important health indicator. ${ }^{4}$ The prevalence of anemia ranges from $30 \%$ to $98 \%$ in different studies from different regions. ${ }^{5}$ Prevalence of anemia in Nepal was $36.2 \%$ in the year 2006 which was shown by WHO Global database on anemia ${ }^{11}$. In our study, anemia was seen in $28.1 \%$ cases among 975 CBC samples run during the study period. Similar finding was seen in a study done in eastern part of Nepal by Sinha et $a l^{12}$ where the prevalence of anemia was $25.6 \%$. Another study done in Nepal showed that the prevalence of anemia among school going children ranged from $31.6 \%$ to $45.3 \%{ }^{13}$ Prevalence of anemia in different part of India is different ranging from $8.7 \%$ to $53.2 \%{ }^{3,5,14}$ Bangladesh also gives similar prevalence rate of anemia which ranges from $43 \%$ to $49 \% .^{15}$

The mean age of the person with anemia was $41.40 \pm$ 25.37 with minimum age of 6 months and maximum age of 93 years in our study. There was more number of cases in age group $\geq 15$ years $(82.8 \%)$. Anemia was more commonly seen in female $(68.2 \%)$ than male $(31.8 \%)$. A study done in different parts of India showed similar finding with more number of cases of anemia in adult age group where females were affected more. ${ }^{6,714}$ Similar finding was seen in a study done in Bangladesh. ${ }^{15}$ These findings were not in agreement with study done in Nepal, where more number of males had anemia. ${ }^{16}$

Hematocrit (Hct) is the volume percentage of RBC in blood. The level of Hct was compared among different age groups and found out that it was statistically significant. Rairikar et $a l^{1}$ also showed that there was a positive correlation between $\mathrm{Hb}$ and $\mathrm{RBC}$ indices whereas negative correlation was seen between $\mathrm{Hb}$ and RDW. In another study done among children of different age groups, Khadiwada et al compared the level of $\mathrm{Hb}$ among different age groups and found that the study was significant. ${ }^{13}$

The classification of anemia is based on the alteration in the red cell morphology and it points to the particular cause. Morphological characteristics like normocytic, microcytic or macrocytic provides etiological clues. ${ }^{3}$ In our study, low MCV (65.33 \pm 5.46) was seen in children of age group 12- 14 years and high MCV (114.64 \pm 5.46$)$ was seen in age group, $\geq$ 15 years. This showed microcytic picture in children and macrocytic in person $\geq 15$ years. Hence, it was seen that macrocytic anemia was the predominant type of anemia in our study. This finding was in contrast to the studies done by Jadhav et $a l^{2}$ Qureshi et $a l^{3}$ and Kerdany et $a l^{17}$ in which microcytic anemia was the predominant type. Several studies had shown that microcytic hypochromic anemia was common and was suggestive of iron deficiency as the etiology. ${ }^{5-8,18-20}$ Studies done in Nepal shows that iron deficiency is very common and it is most commonly seen in females as well as children. ${ }^{12,19,21}$

Macrocytic anemia was also quite common among older adults and comprises of almost $14 \%$ of all anemia cases. ${ }^{20}$ Macrocytosis is the most commonly associated with vitamin B12, folic acid deficiency followed by alcoholism and liver disease. Study had also showed that alcohol and folic acid plays a secondary role in macrocytosis. ${ }^{22}$ Though alcohol consumption is very common among patients who visit our hospital, due to limitation in our study regarding the alcohol intake history we could not conclude the cause of macrocytosis in the group $\geq$ 15.

In our study low $\mathrm{MCH}$ and low $\mathrm{MCHC}$ was very common in children of 12-14 years. MCH is usually decreased in hypochromic anemia. Sex wise comparison of MCH in our study showed that it was statistically significant while other variables like Hct MCV, MCHC and RDW were not significant. Similarly low MCHC was seen in those with low MCV. MCHC was low in all groups except in group $\geq 15$ years. This was the group where MCV level was high too. Contrast to our study, other studies showed that $\mathrm{MCH}$ and MCHC was decreased in most of the cases with anemia. ${ }^{1,2,7}$ The MCH and MCHC was not statistically significant among the different groups in our study.

RDW is a parameter that measures variation in red blood cell size and RDW- CV is expressed in percentage. In our study, RDW was elevated in all the age groups with more elevation in children between 12- 14 years. This was the group with 
decreased $\mathrm{MCV}, \mathrm{MCH}$ and $\mathrm{MCHC}$ which was suggestive of microcytic hypochromic anemia. Associations of RDW with other variables were not found statistically significant. Similar finding was revealed in a study done by Jadhav et al. ${ }^{7}$ Sultana et $a l^{23}$ found that higher level of RDW was significant than MCV, MCH and MCHC in cases of microcytic hypochromic (iron deficiency anemia). In our study, the total number of cases of microcytic anemia was less as it was seen in children of 12-14 years and there were fewer cases in this group. Choudhary et $a l^{24}$ also showed that most of the cases of anemia showed abnormal RDW. There was increase in RDW level with microcytic anemia. Since iron deficiency anemia is the most common type of anemia RDW can be used as an effective tool for the diagnosis. RDW determination had high sensitivity and specificity for early diagnosis of microcytic (iron deficiency) anemia. RDW is usually not done as a part of CBC in developing countries. The use of RDW can be promoted for early detection and starting treatment of iron deficiency anemia. ${ }^{24}$

Reticulocyte count compared to different groups was statistically significant in our study. It was normal in all groups except in children of 12-14 years where the reticulocyte count is low. Different range of reticuolyte count was seen in anemia according to the severity in a study done by Rairikar et al. ${ }^{1}$ Studies had shown that the reticulocyte counts were usually increased in microcytic hypochromic (iron deficiency anemia). 2,5,9 The reticulocyte count indicate different aspects of erythropoietic control, balance of production of red cells in relation to their rate of destruction. ${ }^{10}$ The reticulocyte is also increased in the recovery from a iron deficiency anemia or recovery of erythropoeisis after bone marrow suppression..$^{8,25}$

Prevalence of anemia increases with age and in different age group, the prevalence of various types of anemia is different. Hematological parameters guiding the type of anemia are different in different age group. It gives us the idea about the morphological classification of anemia. In younger age group, the most common is microcytic hypochromic anemia and in adult it is macrocytic. RBC indices are very simple tests which can be easily obtained from automated hematology cell counter. They are very helpful in the classification of anemia and for planning the further management.

\section{REFERENCES}

1. Rairikar SS, Ahire AP, Baheti NR, Patil MA. A study of blood cell indices and reticulocytes count in cases of anemia in females in reproductive age group. MVP J Med Sci 2014; 1: 56-60.

2. Jadhav SU, Khaparde S. Study of the red cell indices, hemogram and platelet variations in anemic (10 gm $\%)$ patients by automatic cell counter in a tertiary care centre, Ahmednagar, Maharastra, India. Int $J$ Res Sci 2017; 5: 1582-8.

3. Qureshi NA, Chauhan MAZ, Goswami AP, Suri Sk. Study of anemia and its correlation with hematological parameters in patient of various age group. J Dental Med Sci 2015; 14: 29-35.

4. Hemoglobin concentrations for the diagnosis of anemia and assessment of severity. Vitamin and mineral nutritional information system (VMNIS), World Health Organisation (WHO) 2011.

5. Verma P, Singh S, Ghildiyal A, Kumar A, Krishna A. Prevalence of anemia in adults with respect to sociodemographic status, blood groups and religion in north Indian population. Int J Biol Med Res 2012; 3: 2422-8.

6. Uria GA, Naik PK, Midde M, Yalla PS, Pakam R. Prevalence and severity of anemia stratified by age and gender in rural India. Hindawi 2014; 10: 1-5.

7. Jadhav MV, Agarwal SA, Kadgi NV, Khedkar SS, Kulkarni KK, Kudrimoti JK. utility of automated RBC parameters in evaluation of anemia. Intl $J$ Healthcare Biomed Res 2015; 3: 170-81.

8. Bessman JD. Walker HK, Hall WD, Hurst JW editors. Clinical methods- the history, physical and laboratory examinations. $3^{\text {rd }}$ ed. Boston Butterworths 1990.
9. Wollmann M, Gerzson BMC, Schwert V, Figuera RW, Ritzel G de O. Reticulocyte maturity indices in iron deficiency anemia. Rev Bras Hematol Hemoter 2014; 36: 25-8

10. Cortellazzi LC, Teixeira SM, Borba R, Gervasio S, Cintra CS, Grotto HZW. Reticulocyte parameters in hemoglobinopathies and iron deficiency anemia. Rev Bras Hematol Hemoter 2003; 25: 97-102.

11. Vitamin and mineral nutritional information system (VMNIS). WHO Global database on anemia 2007.

12. Sinha AK, Majumdar B, Yadav SK. Prevalence and significance of iron deficiency anemia among people of Morang district of Nepal. J Nobel Med Coll 2011; 1 : 40-5.

13. Khatiwada S, Gelal B, Gautam S et al. Anmeia among school children in eastern Nepal. J Trop Ped 2015; 61: 231-3.

14. Gupta SK, Agarwal SS, Kaushal R, Jain A, Gupta VK, Khare N. Prevalence of anemia among rural population living in and around of rural health and training center, Ratua village of Madhya Pradesh. Muller J Med Sci Res 2014; 5: 15-8.

15. Ahmed F. Anemia in Bangladesh- a review of prevalence and aetiology. Public Health Nutr 2000; 3: 385-93.

16. Lamsal KS. Clinical profile of patients with anemia. J Inst Med 2009; 31: 31-3.

17. Kerdany $\mathrm{T}$ Ali El, El Ela SA, Aziz JBS. Study of automated red blood cells parameters in correlation with routine RBCs morphology by smear review. The Egyp J Hosp Med 2017; 68: 1358-63 
18. Baral KP, Onta SR. Prevalence of anemia amongst adolescents in Nepal: a community based study in rural and urban areas of Morang district. Nep Med Coll J 2009; 11: 179-82.

19. Niazii M, Tahir M, Raziq F, Hameed A. Usefulness of red cell indices in differentiating microcytic hypochromic anemias. Gomal J Med Sci 2010; 8: 125-8.

20. Patel KV. Epidemiology of anemia in older adults. Semin Hematol 2008; 45: 210-7.

21. Karki KB, Thapa P, Dhimal M et al. Anemia and its determinants among women of reproductive age in mid western tarai of Nepal 2015. Nep Heath Res Council. 2015.

22. Maruyama S, Hirayama C, Yamamoto S et al. Red blood cell status in alcoholic and non alcoholic liver disease. J Lab Clin Med 2001; 138: 332-7

23. Sultana GS, Haque SA, Sultana T, Ahmed AN. Value of red cell distribution width (RDW) and RBC indices in the detection of iron deficiency anemia. Mymensingh Med J 2013; 22: 370-6

24. Choudhary M, Sharma D, Shekhawat DS, Dabi D. Significance of red cell distribution width in the diagnosis of iron deficiency anemia: an observational study from India. J Pediatr Neonatal Care 2015; 2; 102-6

25. Butthep P, Wisedpanichkij R, Jindadamrongwech $\mathrm{S}$ et al. Reticulocyte analysis in iron deficiency anemia and hemolytic anemia. J Med Assoc Thai 2000; 83: 114-22. 